\title{
Commelina diffusa Population Dynamics in Banana and Ruderal Habitats under Mechanical and Herbicide Management Regimes
}

\author{
Wendy-Ann P. Isaac, Richard A. I. Brathwaite, and Ayub Khan \\ Department of Food Production, Faculty of Science and Agriculture, The University of the West Indies, \\ St. Augustine, Trinidad and Tobago \\ Correspondence should be addressed to Wendy-Ann P. Isaac, wendy-ann.isaac@sta.uwi.edu
}

Received 5 August 2011; Accepted 1 November 2011

Academic Editor: Kent Burkey

Copyright (๑) 2012 Wendy-Ann P. Isaac et al. This is an open access article distributed under the Creative Commons Attribution License, which permits unrestricted use, distribution, and reproduction in any medium, provided the original work is properly cited.

Commelina diffusa is a colonising species of banana orchard habitats in St. Vincent in the Windward Islands of the Caribbean. In the present study, the population dynamics of $C$. diffusa were investigated in response to mechanical weed management with either a rotary string trimmer or glufosinate in ruderal and banana habitats. The study focused on density and size distribution of the weed over time and their response to two weed management strategies. The population dynamics of $C$. diffusa differed between the two habitats. Seedling establishment appeared to be an important factor influencing the dynamics of $C$. diffusa in banana orchards as there was little recruitment of seeds with less flower production compared with ruderal habitats where plants produced more flowers. Plants of $C$. diffusa in the banana orchard habitat had a longer growth cycle. In the banana orchard habitat, the C. diffusa population was greater and the plants were shorter with mechanical management than in areas treated with glufosinate. The results suggest that it is possible to manipulate the dynamics of $C$. diffusa in banana orchards as there is less chance of seed recruitment. Further research is necessary to refine an IPM approach for the management of C. diffusa.

\section{Introduction}

C. diffusa occurs in ruderal and agricultural habitats in the Windward Islands. In the agricultural habitat of St. Vincent and the Grenadines, it is commonly found in banana but it also grows extensively in root crops such as dasheen (Colocasia esculenta (L.) Schott) (personal observation, November 2003). C. diffusa has gained noxious weed status in the Windward Islands for a number of reasons. Banana growers in the Windward Islands since the early 1970s have relied primarily upon the herbicides $2,4-\mathrm{D}$, paraquat, and glyphosate. Heavy reliance and continuous use of these synthetic herbicides have resulted in a number of problems, including the development of herbicide-resistant biotypes of C. diffusa [1]. Since the introduction of fair trade (Fair trade is an organized social movement and market-based approach that aims to help producers in developing countries make better trading conditions and promote sustainability. The movement advocates the payment of a higher price to producers as well as higher social and environmental standards.), in 2002, with its minimal or prohibited use of herbicides, farmers have controlled weeds manually, using the cutlass or using the "rotary string trimmer." Use of the cutlass and rotary string trimmer has intensified the problem of $C$. diffusa by exacerbating the spread of its propagules. Glufosinate is the only herbicide permitted for use by fair trade banana growers at the discretion of the local extension service, when the incidence of $C$. diffusa is above a certain threshold level. Additionally, these Islands are characterized by hilly topography and climate with ideal moisture conditions for the proliferation of $C$. diffusa. Because many of the banana plantations have been farmed for several years with virtually no crop rotations or tillage practices, further stabilization of $C$. diffusa populations has occurred.

C. diffusa Burm. f. is an invasive herbaceous perennial plant which grows either erect or spreading and reproduces vegetatively or by seeds. Generally plants from natural or ruderal habitats invading agricultural habitats encounter new environmental conditions [2]. C. diffusa is a colonising 


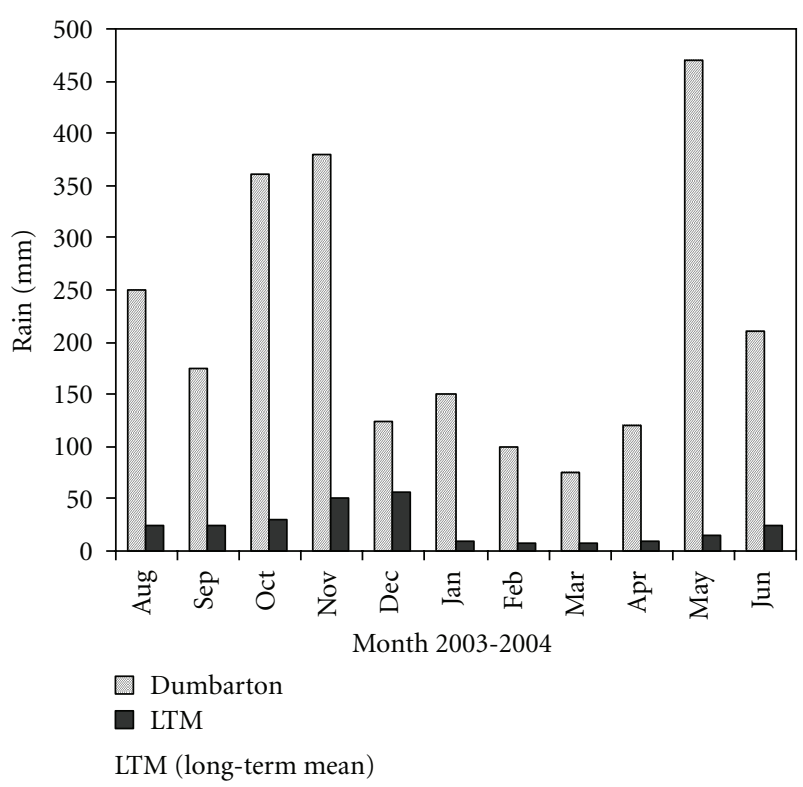

Figure 1: Rainfall (mm) patterns from August 2003-June 2004 at Dumbarton.

species of disturbed areas such as banana fields where it was once introduced to provide ground cover [3, 4]. This species has colonised banana orchard habitats for more than twenty years in some cases where fields have been farmed continuously (SVG (SVG St. Vincent and the Grenadines) farmers, personal communication September 2003). A colonising species may either increase in population size or density and result in high weed populations [5]. Weed populations may vary widely in genotype, age, size, and developmental stage.

Environmental conditions may influence weed population dynamics [2] such as selection pressures which cause evolutionary responses [6] and various management practices which cause temporal and spatial patchiness [7]. It has been suggested that weed management programmes could be improved by taking into account the variability of weed population responses to specific control procedures [8]. The design and evaluation of improved weed management strategies depends on our ability to understand the dynamics of plant populations.

Ruderal populations of $C$. diffusa include shaded roadside and backyard locations. There are no recorded studies on the population dynamics of $C$. diffusa; however, studies have been conducted on the population dynamics of $C$. benghalensis L. under soil and herbicide management practices in Brazil [9] and on C. benghalensis seedbank dynamics and longevity in the United States of America [10].

The objective of the present study was to compare the population dynamics of $C$. diffusa in ruderal and banana orchard habitats, focusing on the size of the plant populations, plant height, and fecundity and their response to two weed management strategies. This study addressed two questions. (i) Do the population dynamics of $C$. diffusa differ between the chosen ruderal and banana orchard habitats and
Table 1: The effect of mechanical and chemical weeding on $C$. diffusa shoot density in banana orchard habitat from September 2003 to May 2004.

\begin{tabular}{lccc}
\hline Month & Check & Glufosinate & $\begin{array}{c}\text { Rotary } \\
\text { string } \\
\text { weeder }\end{array}$ \\
\hline September & $471^{\mathrm{a}}$ & $0^{\mathrm{c}}$ & $64^{\mathrm{b}}$ \\
October & $686^{\mathrm{a}}$ & $0^{\mathrm{c}}$ & $143^{\mathrm{b}}$ \\
November & $955^{\mathrm{a}}$ & $7^{\mathrm{c}}$ & $281^{\mathrm{b}}$ \\
December & $1153^{\mathrm{a}}$ & $21^{\mathrm{c}}$ & $514^{\mathrm{b}}$ \\
January & $1098^{\mathrm{a}}$ & $45^{\mathrm{b}}$ & $35^{\mathrm{b}}$ \\
February & $1197^{\mathrm{a}}$ & $84^{\mathrm{b}}$ & $57^{\mathrm{c}}$ \\
March & $1304^{\mathrm{a}}$ & $109^{\mathrm{b}}$ & $104^{\mathrm{b}}$ \\
April & $1328^{\mathrm{a}}$ & $175^{\mathrm{b}}$ & $205^{\mathrm{c}}$ \\
May & $1861^{\mathrm{a}}$ & $219^{\mathrm{c}}$ & $437^{\mathrm{b}}$ \\
\hline
\end{tabular}

Means between columns for each month followed by the same letter are not significantly different at the 0.05 level.

TABle 2: The effect of mechanical and chemical weeding on $C$. diffusa shoot density at ruderal habitat from September 2003 to May 2004.

\begin{tabular}{lccc}
\hline Month & Check & Glufosinate & $\begin{array}{c}\text { Rotary } \\
\text { string } \\
\text { weeder }\end{array}$ \\
\hline September & $193^{\mathrm{a}}$ & $0^{\mathrm{c}}$ & $60^{\mathrm{b}}$ \\
October & $449^{\mathrm{a}}$ & $0^{\mathrm{c}}$ & $141^{\mathrm{b}}$ \\
November & $803^{\mathrm{a}}$ & $0^{\mathrm{c}}$ & $348^{\mathrm{b}}$ \\
December & $1062^{\mathrm{a}}$ & $18^{\mathrm{c}}$ & $644^{\mathrm{b}}$ \\
January & $1255^{\mathrm{a}}$ & $34^{\mathrm{b}}$ & $48^{\mathrm{b}}$ \\
February & $1153^{\mathrm{a}}$ & $77^{\mathrm{b}}$ & $101^{\mathrm{b}}$ \\
March & $1398^{\mathrm{a}}$ & $146^{\mathrm{b}}$ & $195^{\mathrm{b}}$ \\
April & $1847^{\mathrm{a}}$ & $290^{\mathrm{b}}$ & $346^{\mathrm{b}}$ \\
May & $2555^{\mathrm{a}}$ & $550^{\mathrm{b}}$ & $546^{\mathrm{b}}$ \\
\hline
\end{tabular}

Means between columns for each month followed by the same letter are not significantly different at the 0.05 level.

if so, what may be the possible factors causing the differences? (ii) Do the population dynamics of $C$. diffusa differ between the ruderal and banana orchard habitats in response to two weed management?

\section{Materials and Methods}

2.1. Sites. One ruderal and one agricultural site were selected in St. Vincent for this study in August 2003 using only sites where the $C$. diffusa populations had an average height range of $10-26 \mathrm{~cm}$ and more than 100 shoots $/ \mathrm{m}^{2}$. Care was taken to ensure that $C$. diffusa was carefully identified at both sites before trials were conducted. The ruderal site was located in Orange Hill which was about $2 \mathrm{~km}$ away from the nonirrigated banana orchard located in Langley Park. Both locations were on relatively flat areas of St. Vincent (predisposed to slight erosion with a slope of $0-5^{\circ}$ ), and 


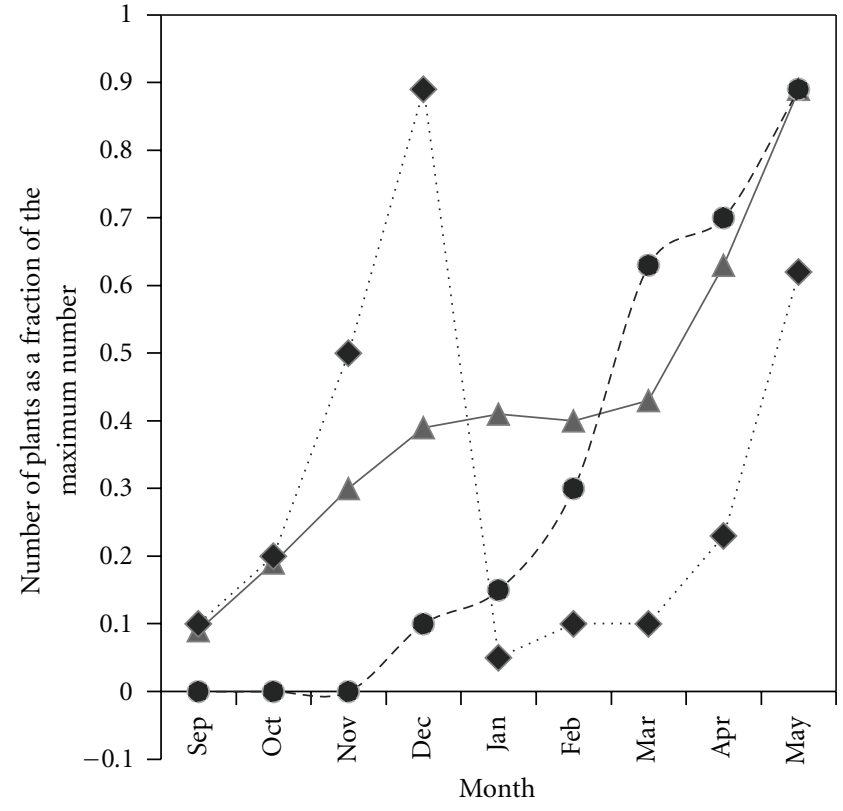

(a)

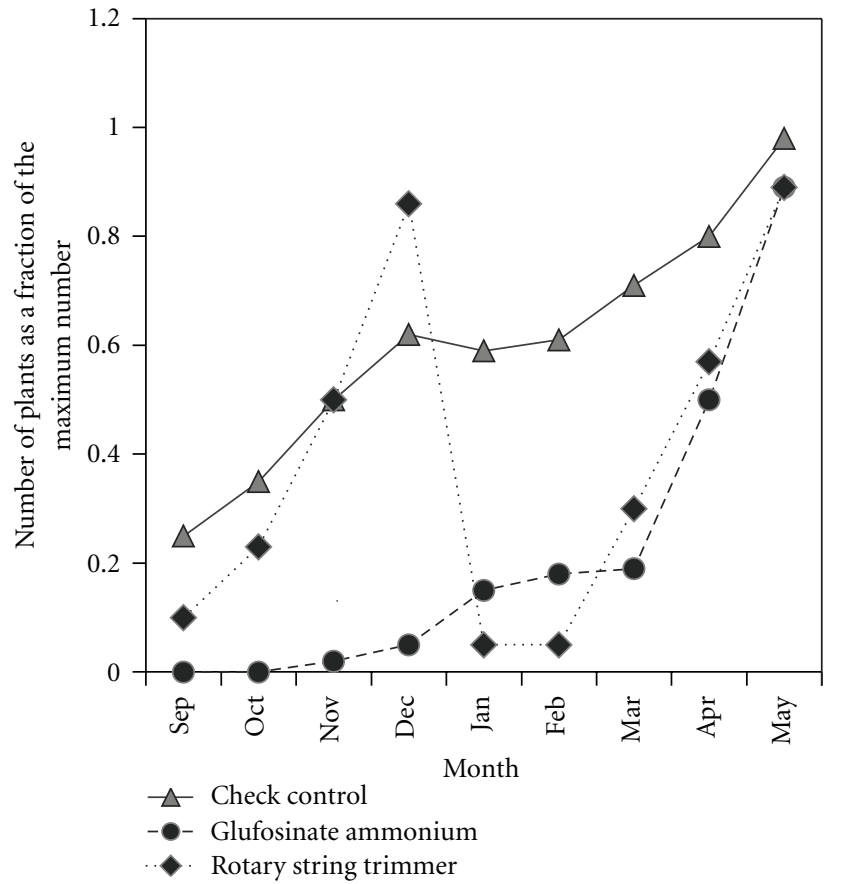

(b)

Figure 2: Population dynamics of C. diffusa at (a) banana and (b) ruderal habitats from September 2003 to May 2004. Plant numbers are expressed as a fraction of the maximum number of plants determined at each site for the whole period of study.

the soil type was a Soufrière cindery gravely sandy loam (recent volcanic ash).

2.2. Experimental Design and Data Collection. An area of $15 \mathrm{~m}$ by $15 \mathrm{~m}$ was preferred for evaluation, but there was a difficulty in allocating this size at the ruderal site, so $5 \mathrm{~m} \times 5 \mathrm{~m}$ plots had to be marked out where there was a higher incidence of $C$. diffusa. Plots measuring $5 \mathrm{~m} \times 5 \mathrm{~m}$ were allocated for applying 3 treatments which were replicated 3 times giving a combined total of 18 plots at both sites, arranged in a randomised complete block design. Treatments included (1) two mechanical weedings with a Stihl rotary string trimmer (Stihl USA Incorporated, Rotary String Trimmer, P.O. Box 2015, Virginia Beach, VA 23450-2015, USA) one on August 16, 2003 and after shoot numbers were recorded on December 18, 2003, (2) one herbicide application of glufosinate-ammonium (Basta (Basta, (Glufosinate-ammonium), Jon Fischer Bayer CropScience LLC, 5315 Indigo Way, USA)) applied with a CP3 (Cooper Pegler) (Hand pumped CP3 (Cooper Pegler) Knapsack sprayer, Hardi international A/S, Helgehøj Allé 38, DK 2630 Taastrop, Denmark) knapsack (20 litre) sprayer at a rate of $0.68 \mathrm{~kg}$ ai/ha using a TeeJet $800 \mathrm{LE}$ cone-nozzle $(8001 \mathrm{E}$ cone nozzle, TeeJet, P.O. Box 7900, Wheaton, IL 60189-7900, USA), (3) a nontreated check where no weed management was conducted.

Treatments were applied in mid-August during the rainy season as plants were actively growing and at various stages of development. The number of plants in each plot was determined by subdividing $5 \mathrm{~m}$ plots into 25 quadrats of $1 \mathrm{~m} \times 1 \mathrm{~m}$. A permanent quadrat measuring $0.25 \mathrm{~m} \times 0.25 \mathrm{~m}$ was placed in each $1 \mathrm{~m} \times 1 \mathrm{~m}$ plot from which observations on the growth and development of plants were made. Shoots were counted and tagged with plastic-coated wires at monthly intervals beginning one month after treatments were applied from September 2003 to May 2004. All C. diffusa shoots were counted within the $1 \mathrm{~m} \times 1 \mathrm{~m}$ plot.

Plants at both sites were classified according to (1) seedling density, (2) vegetative internode/stem elongation, (3) flower initiation, (4) flowering, (5) capsule formation, and (6) seed set on a monthly basis. Crop production practices at the banana habitat were in compliance with fair trade criteria. Precipitation and air temperatures were recorded daily at a weather station located at Dumbarton less than $5 \mathrm{~km}$ away from both sites. Weather data were segmented into various periods corresponding with the major growth stages of the population.

2.3. Data Analysis. Data were subjected to analyses of variance (ANOVA) using SPSS (SPSS software, Version 11.0 for Windows, SPSS Inc. Headquarters, 233. S Wacker Drive, 11th Floor Chicago, Il, 606066, USA) (Version 11.0 for Windows) with a significance level of 0.05. Means were separated using least significance differences (LSD) also at the 0.05 significance level. Habitats were analysed separately. Analyses were performed on (1) seedling density, (2) vegetative internode elongation, (3) flower initiation, (4) flowering (5) capsule formation, and (6) seed set. 


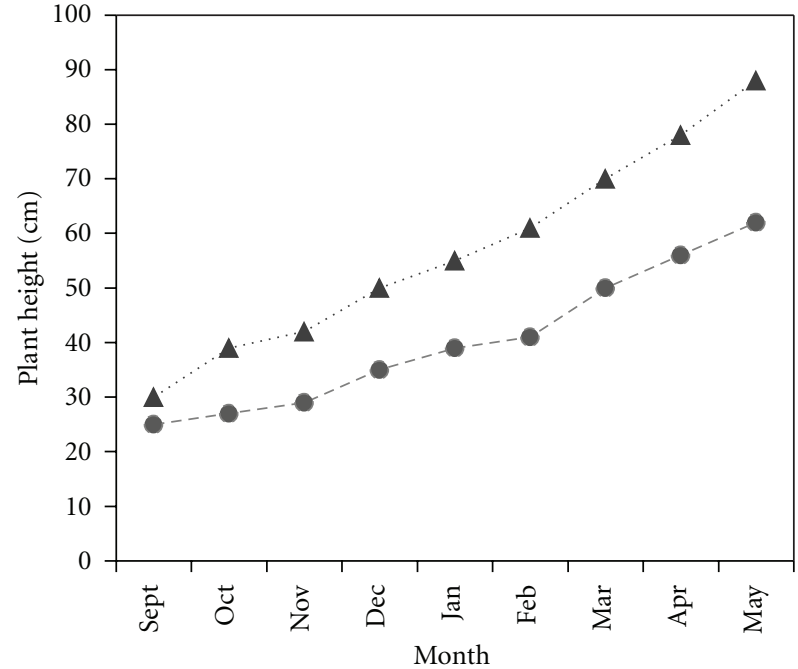

(a)

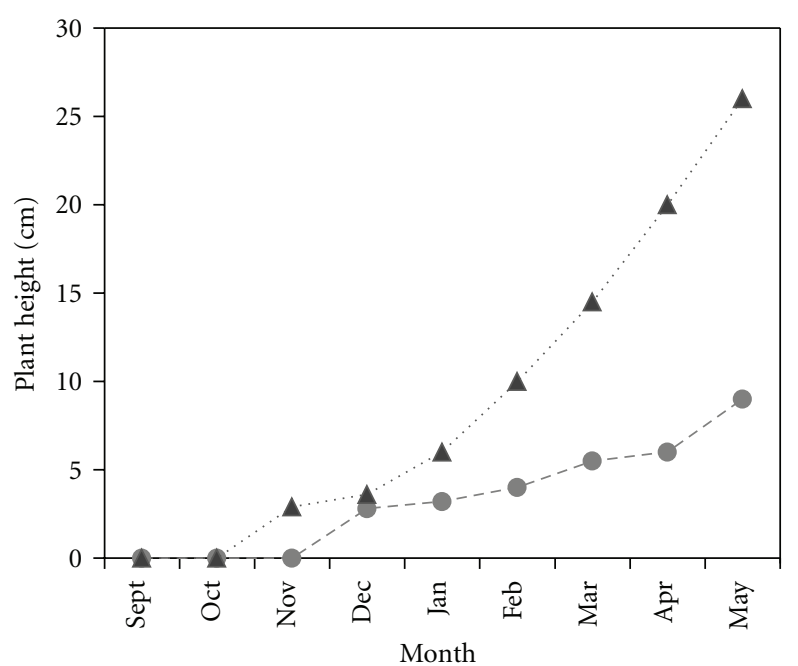

(b)

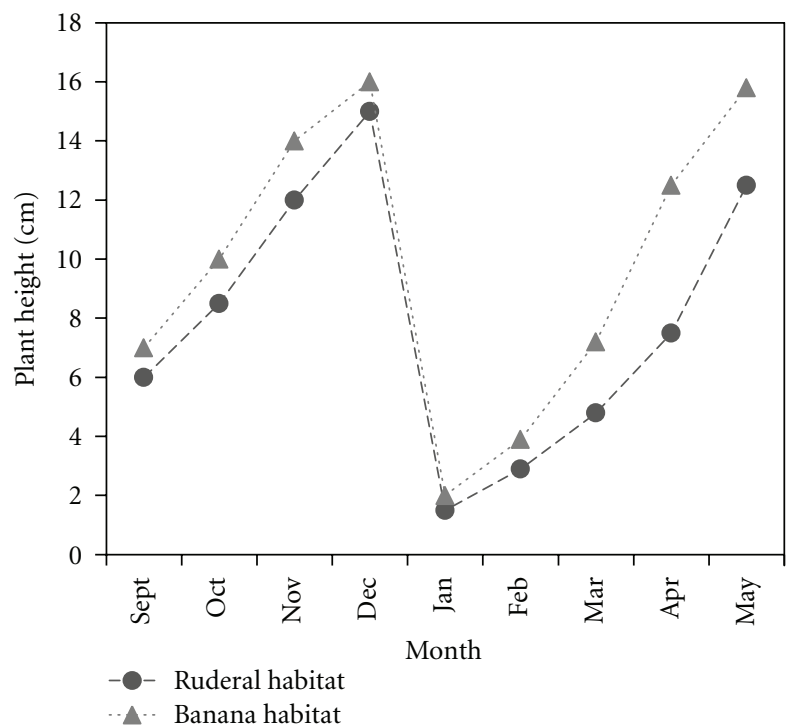

(c)

Figure 3: Mean plant height ( $\mathrm{cm}$ ) of nontreated control (a), glufosinate ammonium-treated (b), and rotary trimmer-treated (c) C. Diffusa at ruderal and banana orchard habitats from September 2003 to May 2004.

\section{Results and Discussion}

Vegetative and reproductive characteristics of $C$. diffusa differed significantly between habitats and treatments. In particular, node elongation, shoot number, reproductive buds, flower and capsule number, were all affected by habitat, treatment, and time. Rainfall patterns for this period were extremely higher than previous years, and this could explain the variations in shoot numbers (Figure 1). Rainfall increased from September to November by $205 \mathrm{~mm}$, decreased from November to March by $305 \mathrm{~mm}$, and then increased again from March to May by $395 \mathrm{~mm}$. C. diffusa is highly dependent on adequate moisture levels for growth [11]; therefore, greater proliferation was expected as a result of increased rainfall.
The population density of $C$. diffusa in both banana and ruderal habitats showed similar patterns across treatments. From September 2003 to January 2004 shoot numbers increased rapidly, decreasing slightly in December, and continuing to increase from February to May for the nontreated check (Tables 1 and 2). Where glufosinate ammonium was applied, C. diffusa were controlled for approximately two to three months before any stems rejuvenated. Plants in the ruderal habitat appeared to take a longer time to initiate recovery than those in the banana orchard habitat suggesting possible genotypic differences that permit adaptations to the habitats. The rate of regeneration of $C$. diffusa stems was higher for stems that were cut using the rotary string trimmer compared to the check control treatment. Overall, the rate of regeneration was faster in the banana orchard than at 


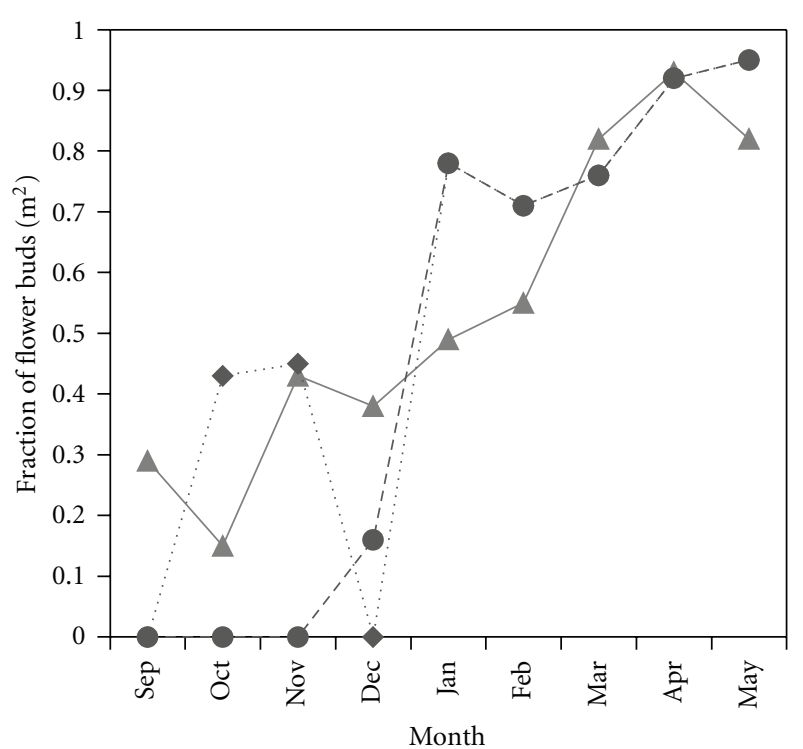

(a)

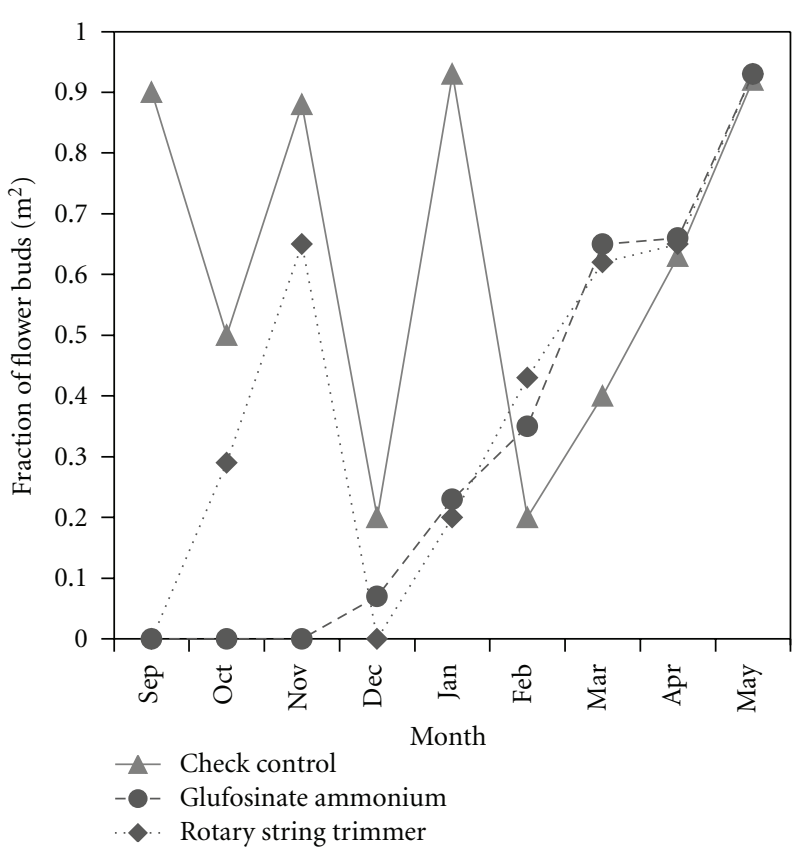

(b)

FIgURE 4: Stage of reproduction of C. diffusa at (a) banana and (b) ruderal habitats. Flower bud numbers are expressed as a fraction of the total tagged shoots from the previous month at each site for the whole period of study.

the ruderal habitat for all treatments. It was difficult to quantify plant mortality because of the mat-like mass produced by stems at the base of sprawling stems of C. diffusa. Tagged plants without any green tissue were considered dead.

Figures 2(a) and 2(b) show the population dynamics of $C$. diffusa at the ruderal and banana habitats from September 2003 to May 2004 as a fraction of the maximum number of plants determined at each site for the whole period of the study. Trends in population (shoot numbers) development were similar at both habitats for all treatments. In both habitats there was a relatively large size hierarchy of individuals during the whole trial period in the nontreated check treatment compared to the other treatments.

Plant height ranged from 1.7 to $93.5 \mathrm{~cm}$ and varied between treatments and time of the year (Figure 3). Plant height was higher in the banana habitats probably because of the fertilizer inputs which invariably indicate that there may have been competition as a result of higher nutrient levels as pointed out by [12].

Check plants in the ruderal habitat were severely infected with Uredinales rust fungi whereas there was no incidence in the banana orchard habitat. The incidence of rust fungi data was therefore not analysed. Attempts to isolate/culture the rust for proper identification were unsuccessful. The incidence of rust fungi reduced $C$. diffusa leaf area as mature leaf (leaf length $>4-6 \mathrm{~cm}$ ) numbers were very low; however, internode elongation continued as well as new shoot development. Plants recovering from mechanical and herbicide treatments in the ruderal habitat showed no incidence of rust fungi from time of recovery to final date of data collection in May. This suggests that the disturbance caused by the application of the various management techniques may have contributed to a disruption in the cycle of the rust fungi.

There appeared to be no set period for sexual reproduction as flowering and capsule formation occurred in the nontreated check throughout the trial period in both habitats (Figure 4). Plants in the ruderal habitat had a higher reproductive allocation as there was more emphasis on production of flowers and seed production. This may have been due to the high stress on plants imposed by high rust fungi incidence thus indicating some degree of plasticity. The plasticity in components of reproduction was important to plant fitness as it affects both the number and quality of offspring produced when environmental conditions vary as suggested by [13]. It was proposed that plants will respond to stress primarily by increasing or decreasing seed number [14].

Interestingly, the banana orchard habitat responded differently to increased stress (mechanical manipulation) by extending the vegetative (through increased stem height/internode elongation) growth stage rather than the reproductive growth stage. Plants in this habitat were also subjected to the farmer's agronomic practices including the application of a high nitrogen and potassium fertilizer $(13: 7: 23+3.5 \mathrm{MgO})$ which was broadcast at a rate of $12.5 \mathrm{~kg} / \mathrm{ha}$ to banana plants at least four times (every two months) over the duration of this trial. It is not known what effect this may have had on the growth and development of $C$. diffusa plants. Invasive Commelina species grew faster at higher nutrient levels as reported by [12]. Although severe stunting was reported on $C$. diffusa by high nitrogen authors in $[15,16]$ reported altered growth and physiological characteristics for different Commelina species clones with 
both nitrogen and phosphorus fertilizers. The type of plasticity exhibited by plants to changes in the amount of nutrients has been described by various authors [17, 18]. This plasticity may include variation in resource allocation, morphology, physiology, and reproduction [13]. Plasticity has also been reported in response to herbivore damage [19], but no reports have shown responses to damage caused by rust fungi.

Early stress (first three weeks after emergence) may alter plant size and flower number while stress imposed late in the season may only affect seed mass and seed number per fruit, because the components of reproduction are determined at different times in plant development as indicated by [13]. This was confirmed in the present study in plots treated with glufosinate ammonium and the rotary string trimmer. This early stress significantly altered the plant size of plots treated with the herbicide. Plots treated with the rotary string trimmer were able to respond within a few days (about 12-14 days after application) by the resprouting of cut stems from axillary buds. Stem cuttings which are spread over a wider area are now capable of rooting at the internodes as indicted by [11]. Even a repeat application of this treatment at both habitats resulted in a high rate of growth shortly after.

Mortality was low throughout the trial period for all plant developmental stages (data not presented). The reproductive stage evidenced by flower initiation, flowering, and capsule formation remained fairly constant in the check control compared to the other treatments over time in both habitats. In September a fraction of 0.28 and 0.91 of the tagged shoots in October was in the stage of reproduction for banana and ruderal habitats, respectively, (in the stages of flowering or setting seed). Flowering continued for the duration of this investigation for the check control (Figures 4(a) and 4(b)). Reproduction was significantly affected by herbicide and rotary string trimmer interventions throughout the trial. Recovery of the reproductive capacity of $C$. diffusa occurred from December to April for plots treated with glufosinate ammonium in both habitats. Six weeks after the intervention with the rotary string trimmer, $C$. diffusa plants recovered and were at initial stages of reproduction (buds and capsules) at both habitats. The rate at which these plants recovered was significantly higher than the glufosinate ammonium treatments.

\section{Conclusions}

The population dynamics of $C$. diffusa differed between the ruderal and the banana orchard habitats. Seedling establishment appeared to be an important factor influencing the dynamics of $C$. diffusa in banana orchards as there was little recruitment of seeds with less flower production compared with ruderal habitats where plants produced more flowers. Plants of $C$. diffusa in the banana orchard habitat had a longer growth cycle than in the ruderal habitat where more flowers were produced. At the banana orchard habitat, where C. diffusa is altered due to weed management measures, population numbers were larger in mechanical management than in herbicide managed areas but of lower shoot height after two trimmings. C. diffusa plants in the ruderal control habitat were infected by the Uredinales rust fungi, which severely reduced leaf area. The fungus did not occur in plants in the banana habitat.

It is concluded that knowledge of the population dynamics of $C$. diffusa is essential for developing an effective integrated approach to weed management. The present study demonstrated that the population dynamics of $C$. diffusa can be manipulated by adopting timely weed control measures in banana habitats. The persistence of $C$. diffusa, despite these various control strategies, demonstrates that there is need for improved management approaches including the use of cover crops.

\section{References}

[1] H. W. Hilton, "Herbicide tolerant strains of weeds," Hawaiian Sugar Planters Association Annual Report, Honolulu, Hawaii, USA, 1957.

[2] K. A. Leiss and H. Müller-Schärer, "Adaptation of Senecio vulgaris (Asteraceae) to ruderal and agricultural habitats," American Journal of Botany, vol. 88, no. 9, pp. 1593-1599, 2001.

[3] J. E. Edmunds, "Association of Rotylenchulus reniformis with "Robusta" banana and Commelina sp. Roots in the Windward Island," Tropical Agriculture, vol. 48, no. 1, pp. 55-61, 1971.

[4] N. W. Simmonds, Bananas, Longmans, London, UK, 1959.

[5] P. D. Putwain, K. R. Scott, and R. J. Holliday, "The nature of resistance to triazine herbicides: case histories of phenology and population studies," in Herbicide Resistance in Plants, $\mathrm{H}$. M. LeBaron and J. Gressel, Eds., pp. 99-115, Wiley and Sons, New York, NY, USA, 1982.

[6] M. L. Navas, "Using plant population biology in weed research: a strategy to improve weed management," Weed Research, vol. 31, no. 4, pp. 171-179, 1991.

[7] A. M. Mortimer, "Population ecology and weed science," in Perspectives on Plant Population Ecology, R. Dirzo and J. Sarukhan, Eds., pp. 363-388, Sinauer Associates Inc, Mass, USA, 1984.

[8] J. M. van Groenendael, "Patchy distribution of weeds and some implications for modelling population dynamics: a short literature review," Weed Research, vol. 28, pp. 437-441, 1988.

[9] E. Voll, D. Karam, and D. L. P. Gazziero, "Population dynamics of Commelina benghalensis L. under soil and herbicide management practices," Pesquisa Agropecuaria Brasileira, vol. 32, no. 6, pp. 571-578, 1997.

[10] M. G. Burton, A. C. York, T. M. Webster, and E. P. Prostko, "Demography and distribution of troublesome dayflowers," in Proceedings of the Beltwide Cotton Conferences, pp. 2226-2227, San Antonio, Tex, USA, January 2006.

[11] L. G. Holm, D. L. Pluknett, J. V. Pancho, and J. P. Herberger, The World's Worst Weeds: Distribution and Biology, The University Press, Honolulu, Hawaii, USA, 1977.

[12] J. H. Burns, "A comparison of invasive and non-invasive dayflowers (Commelinaceae) across experimental nutrient and water gradients," Diversity and Distributions, vol. 10, no. 5-6, pp. 387-397, 2004.

[13] D. L. Marshall, N. J. Abrahamson, J. J. Avritt et al., "Differences in plastic responses to defoliation due to variation in the timing of treatments for two species of Sesbania (Fabaceae)," Annals of Botany, vol. 95, no. 6, pp. 1049-1058, 2005.

[14] J. L. Harper, P. H. Lovell, and K. G. Moore, "The shapes and sizes of seeds," Annual Review of Ecology, Evolution, and Systematics, vol. 1, pp. 327-356, 1970. 
[15] J. A. Shcherbakova, "The effect of sowing depth of agricultural crops and fertilizers on the growth and development of Commelina communis," Sibirskii Vestnik Sel'skokhozyaistvennoi Nauki, vol. 6, pp. 33-37, 1974.

[16] R. Urich, I. Coronel, D. Silva, M. Cuberos, and R. D. Wulff, "Intraspecific variability in Commelina erecta: response to phosphorus addition," Canadian Journal of Botany, vol. 81, no. 9, pp. 945-955, 2003.

[17] D. L. Marshall, "Integration of response to defoliation within plants of two species of Sesbania," Functional Ecology, vol. 3, no. 2, pp. 207-214, 1989.

[18] F. Valladares, S. J. Wright, E. Lasso, K. Kitajima, and R. W. Pearcy, "Plastic phenotypic response to light of 16 congeneric shrubs from a panamanian rainforest," Ecology, vol. 81, no. 7, pp. 1925-1936, 2000.

[19] C. M. Mabry and P. W. Wayne, "Defoliation of the annual herb Abutilon theophrasti: mechanisms underlying reproductive compensation," Oecologia, vol. 111, no. 2, pp. 225-232, 1997. 


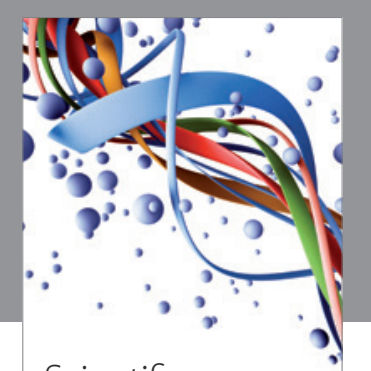

Scientifica
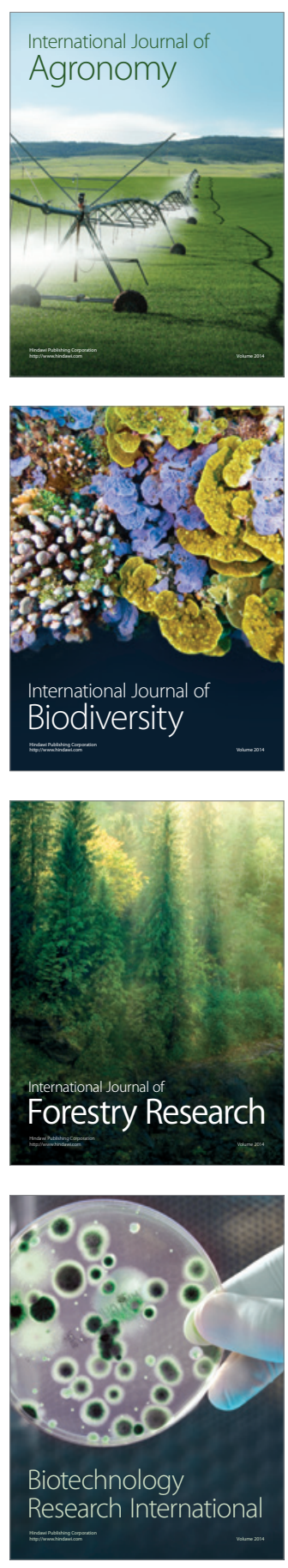
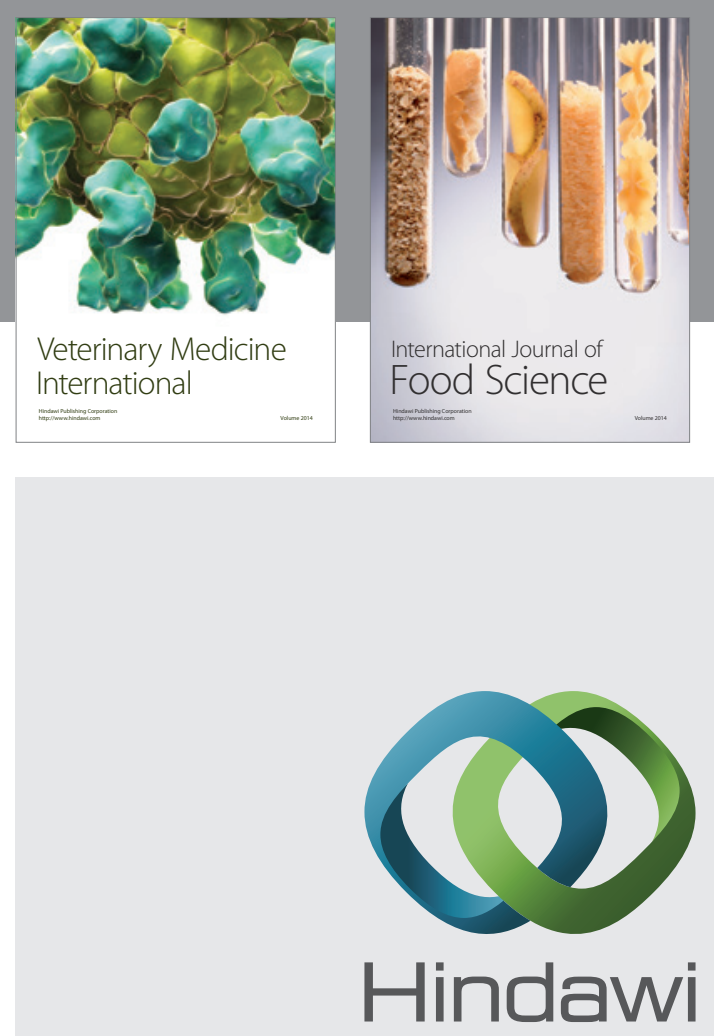

Submit your manuscripts at

http://www.hindawi.com
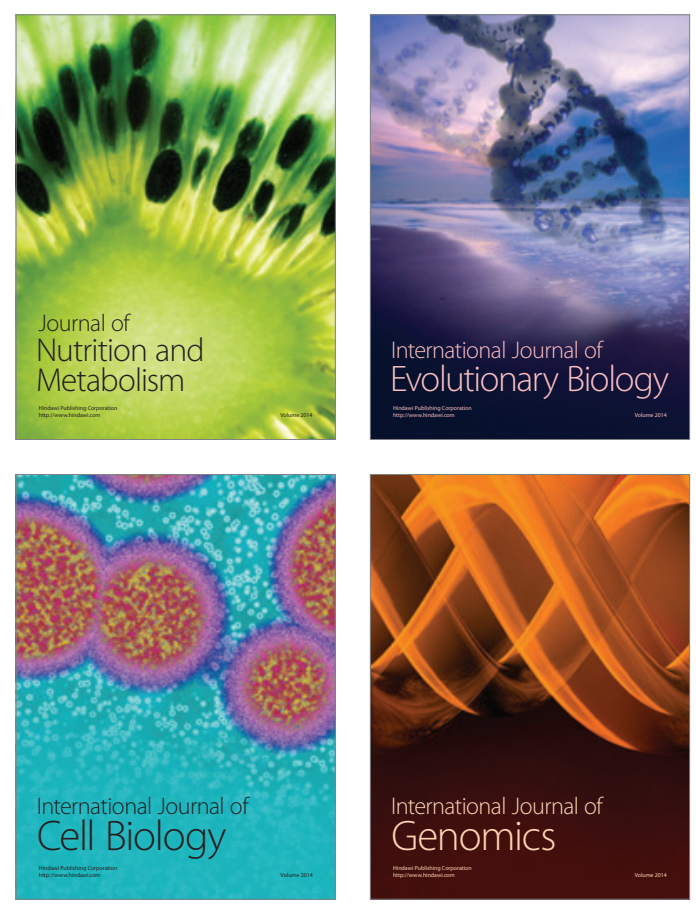
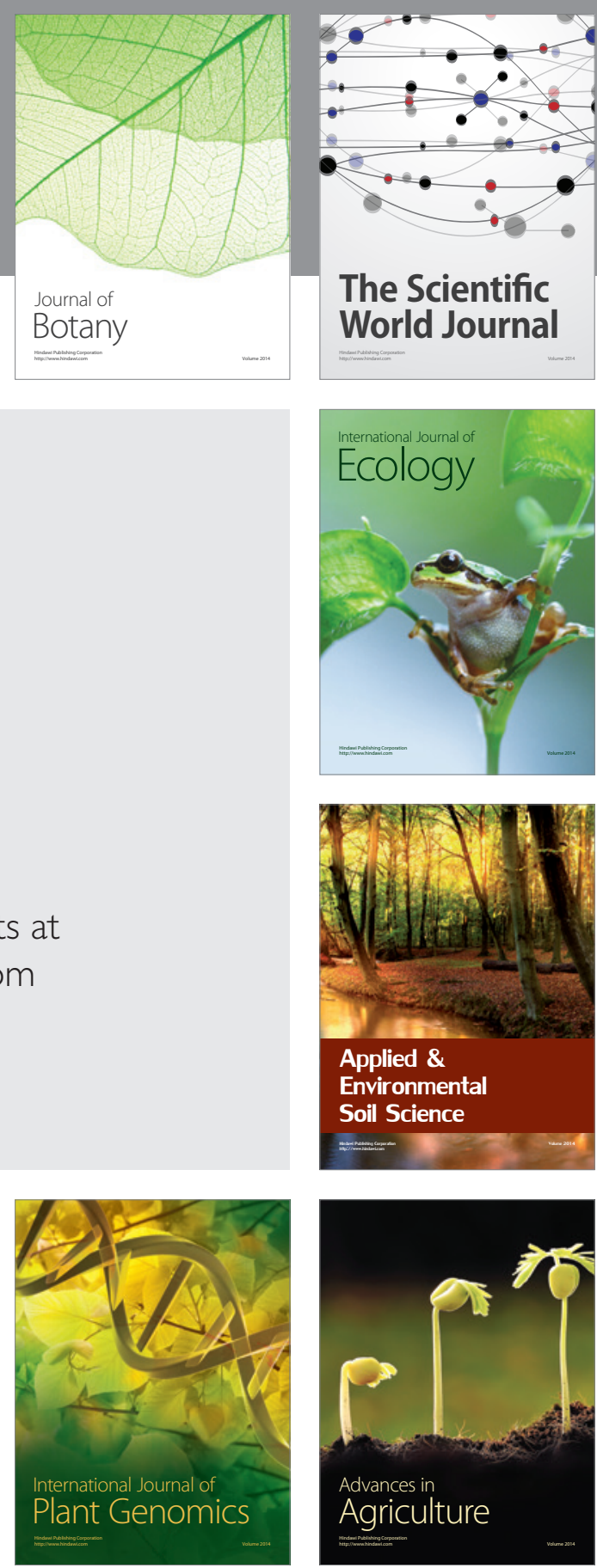

The Scientific World Journal
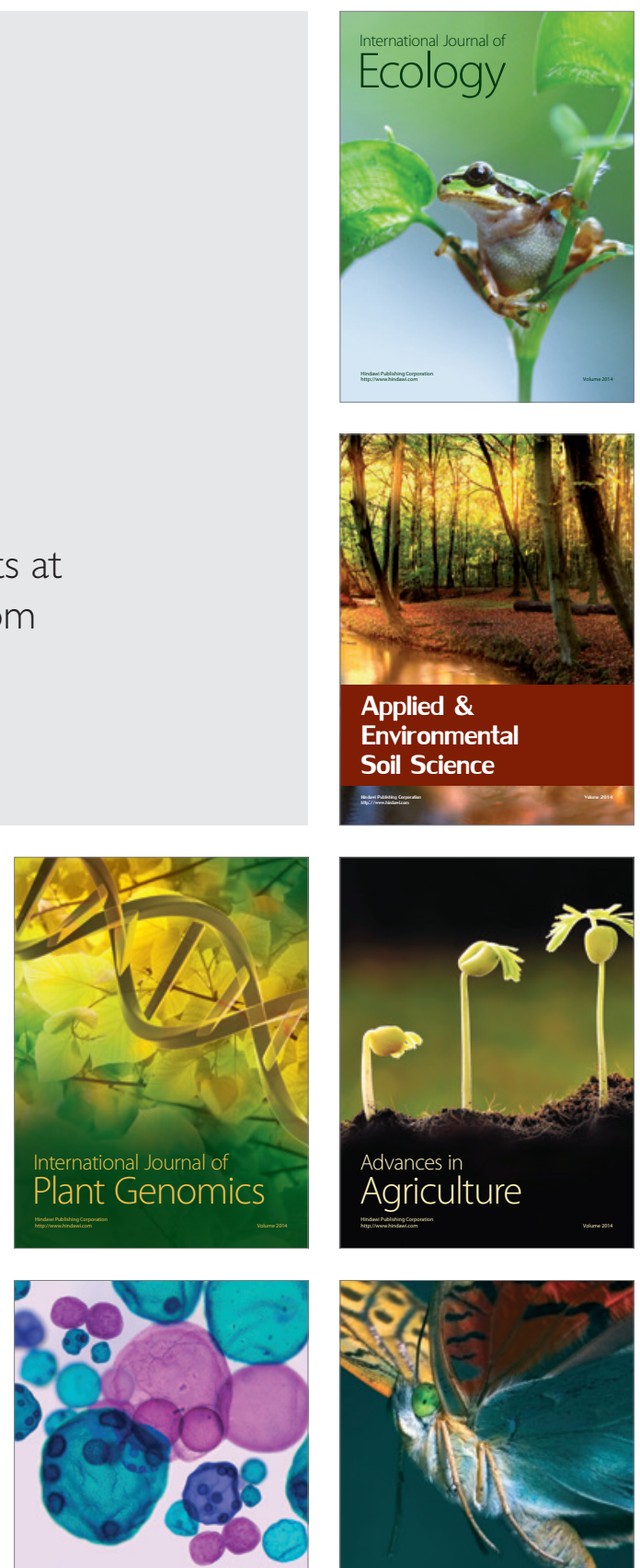

International Journal of Microbiology

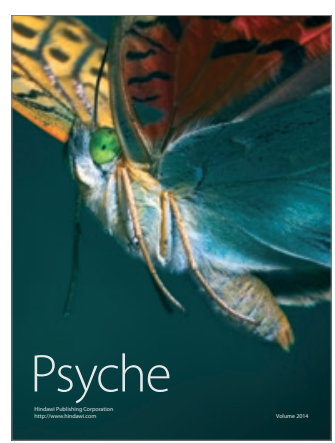

